\title{
Relationships between physical variables, stimuli anaerobic power and muscle damage levels provided by Small-sided game in professional football players.
}

\author{
Abstract \\ Gustavo B. Tognolo (IC), Cristian Lizana (PG), Alcides J. Scaglia (PQ) \\ This study aimed to study the relationship between physical capacities, performance of soccer players during \\ a Small-sided game (SSG) and the magnitude of the adaptive microtraumas (AMT) through the plasma \\ levels of CK. Through the videogrammetry was possible to measure the distance and the speed of the \\ athletes during the SSG. \\ Keywords: Small-sided game, Anaerobic Power, Muscle Damage.
}

\section{Introduction}

This study arose from the need to update the form of training football in Brazil, since this method is considered by scholars of the area as technicistic and decontextualized from the process of systemic organization present in collective games (SCAGLIA, 2003). The trends in training that supported this study treat the game as a complex phenomenon (GARGANTA, 1995). The objective was to study the relationships between the physical capacities, the performance of the participants in a Small-sided game (SSG) and the magnitude of adaptive microtrauma (AMT) through the plasma levels of $\mathrm{CK}$.

The game had an interval feature, were performed series of $1 \mathrm{~min}$ of action with pauses of 2 minutes and the total time was $50 \mathrm{~min}$. The same was done in a field of $20 \times 35 \mathrm{~m}$ with official goals and the presence of goalkeepers in the format $3 \times 3$.

\section{Results and Discussion}

\begin{tabular}{ccccc}
\hline \multirow{2}{*}[\mathrm{CK}]{$(\mathrm{U} / \mathrm{L})$} & \multicolumn{2}{c}{$>400$} & \multicolumn{2}{c}{$<400$} \\
& Media \pm SD & \multicolumn{2}{c}{ Media \pm SD } \\
\hline Travelled & 2650,8 & 225,9 & 2660,8 & 181,5 \\
Distance (m) & & & & \\
$0-4,9 \mathrm{~km} / \mathrm{h}(\%)$ & $19,9 *$ & 3,3 & $24,0 *$ & 3,3 \\
$5-9,9 \mathrm{~km} / \mathrm{h} \mathrm{( \% )}$ & 28,7 & 4,0 & 26,7 & 1,5 \\
$10-14,9 \mathrm{~km} / \mathrm{h} \mathrm{( \% )}$ & 26,1 & 1,6 & 24,3 & 2,4 \\
$15-19,9 \mathrm{~km} / \mathrm{h} \mathrm{( \% )}$ & 18,1 & 4,5 & 17,0 & 1,7 \\
$>20 \mathrm{~km} / \mathrm{h} \mathrm{( \% )}$ & 7,2 & 1,9 & 8,0 & 1,6 \\
\hline
\end{tabular}

Table 1 - Total distance traveled and percentages of distance traveled in each speed range in the SSG. * Indicates significant difference with $p<0.05$ (one-way ANOVA).
The physical tests did not differ between groups and there were no relations of the same with the variables obtained in the execution of the SSG. The group that showed values in CK plasma concentration above 400 (U/L) traveled a significantly smaller distance than the group with lower values. However, the values found in the other intensities were similar. This may be related to contribution of a more effective recovery in interval moments from the SSG actions performed by this group (GILL et al., 2006). This way in a training process that uses the game as a methodological tool, the coaching staff should observe and make sure the breaks provided throughout the session athletes traverse the shortest distance possible.

\section{Conclusions}

We can conclude that it is possible to promote high-intensity stimuli by using the SSG; however, a detailed monitoring of all the variables involved in the training process to adjust the content to the individual needs of athletes is required.

\section{Acknowledgement}

I thank my mentors, Alcides Scaglia and Cristian Lizana for all the help and the opportunity to start my journey of academic research.

\footnotetext{
1 GARGANTA, J. Para Uma Teoria dos Jogos Desportivos Colectivos. "O Ensino dos Jogos Desportivos". $2^{\mathrm{a}}$ Edição. Faculdade de Ciências do Desporto e da Educação Física. Universidade do Porto: Porto, 1995.

2 GILL, N. D., BEAVEN, C. M. \& COOK, C Effectiveness of post-match recovery strategies in rugby players. Br. J. Sports Med. 2006; 40; 260-263 doi:10.1136/bjsm.2005.022483

3 Scaglia, A J. O futebol e os jogos/brincadeiras com os pés: todos semelhantes todos diferentes. Tese de Doutorado pela Universidade Estadual de Campinas, 2003.
} 